\title{
Psychometric properties of the Scale for Evaluating Attitudes towards Seniors (SEAS)
}

\author{
Jacek Łukasiewicz ${ }^{1, A-F}$, Wiesław Kowalski ${ }^{1, A, E}$, Tomasz Saran ${ }^{2, E}$, Anna Mazur ${ }^{2 C, E}$ \\ ${ }^{1}$ University of Economics and Innovation, Lublin, Poland \\ 2 Department of General and Neuro Rehabilitation, Witold Chodźko Institute of Rural Health, Lublin, Poland \\ $A$ - Research concept and design, B - Collection and/or assembly of data, C - Data analysis and interpretation, \\ $D$ - Writing the article, $E$ - Critical revision of the article, $F$ - Final approval of article
}

\begin{abstract}
Łukasiewicz J, Kowalski W, Saran T, Mazur A. Psychometric properties of the Scale for Evaluating Attitudes towards Seniors (SEAS). Ann Agric Environ Med. 2019; 26(2): 309-314. doi: 10.26444/aaem/93107
\end{abstract}

\begin{abstract}
Introduction. The Scale for Evaluating Attitudes towards Seniors (SEAS) was developed based on the concept of social attitudes towards the elderly by G. Miałkowska. The main objective of the study was validation of Scale.

Materials and method. The validation procedure was carried out on a sample of 304 adults. Content validity was estimated based on the CVR coefficient, the theoretical validity was verified by means of exploratory factor analysis with simple Oblimin rotation and Kaiser normalization, and criterion validity determined based on analysis of the correlation matrix of SEAS from IVE and SES. Reliability of the tool was estimated based on the values of alpha Cronbach and the discriminatory power of test items coefficients.

Results. Content validity rates CVR range from $0.83-1.00$. Three SEAS factors were distinguished on the basis of factor analysis - Respect and Support, Rejection and Misunderstanding, Social distance. Their alpha Cronbach's coefficient range is $0.93-0.86$. Extracted SEAS scales correlate with IVE and SES dimensions.

Conclusions. The validation procedure confirms the high psychometric properties of the constructed research tool and allows its use in both individual diagnosis and scientific research, which in turn will contribute to broadening of knowledge about the psychological mechanisms associated with seniors' perception, and can be used to design responses to preventive actions supporting quality of intergenerational interpersonal interactions.
\end{abstract}

\section{- Key words}

attitudes towards seniors, elderly people, psychometric properties of the scale

\section{INTRODUCTION}

The world of values and views promoted today, such as the cult of thebody, strength, health or beauty, leads to the perception of old age in negative categories (disease, disability, burden for the environment, isolation). There are also stereotypes definitely positively associating old age; among others with wisdom, life experience, stability and understanding. Such views have become the basis for construction of the Scale for Evaluating Attitudes towards Seniors (SEAS) by Jacek Łukasiewicz and Wiesław Kowalski.

The SEAS was developed in relation to the belief in the existence of stereotypes that are the source of shaping society's attitudes towards older people [1]. Referring to the values and views promoted today (cult of the body, strength, health or beauty), old age is often perceived negatively (associated with illness, disability, dependence on the environment, small initiative, and ultimately - with a burden on others, or lack of respect) [2]. Such negative attitudes towards the elderly can be referred to as the concept of ageism, which at the end of the 1970s was introduced into the American literature by the gerontologist Robert Bulter [2-4]. Its wider meaning concerns the stereotypical assignment of various psycho-physical features - especially negative ones - to the respective age groups. There are, of course, stereotypes that in a clearly positive way describe older people. They emphasize

Address for correspondence: Jacek Łukasiewicz University of Economics and Innovation in Lublin, Projektowa 4, 20-209 Lublin, Poland e-mail: jlukasiewicz@scj.pl

Received: 12.06.2018; accepted: 10.07.2018; first published: 02.08.2018 such features as: life experience, wisdom, stability, respect, caring and understanding [5].

It should be mentioned that both positive and negative connotations accompanying the image of older people are the source of specific references and attitudes towards them [6-8]. They translate into the way older people are treated. This is particularly important in the case of this part of society that lives on a daily basis with elderly people (mainly the family) and those caring for them (medical staff, carers, employees of services, and others) [9].

The beginning of the 21st century was full of research on knowledge and attitudes relating to older people. A significant part of these efforts referred to the so-called assistance professions in which the direct contact and aiding seniors is among its main objectives. Such research took place, among others, in Greece, Australia, Belgium, Turkey, Jordan, China, Ireland and Poland [10-11]. Some of those confirmed the presence of stereotypes characteristic of ageism [12-14]. Nevertheless, there is a certain bipolarity in the attitudes presented by the respondents. Some demonstrated a positive image of the elderly, with younger generation being grateful for the values, care, interest and feeling of being loved [15]. Negative attitudes towards the elderly most often bound the elderly person with socially difficult and socially disruptive behaviours and personality traits [15].

Analyzes of research results have also revealed factors shaping attitudes towards seniors. The most frequently mentioned include: age of the examined person, gender, opinions taken from the family home, education level, and the so-called cult of youth [15]. It is worth emphasizing that 
the age at which the person is considered older $[15-16]$ is also perceived differently. In different age groups and cultures, it varies from 60 up to as many, as 75 years old.

Numerous studies in the field of gerontology concern the consequences of attitudes towards seniors, and thus specific behaviours of individuals and entire communities. Most analyzes draw attention to the negative consequences that are reflected directly on the oldest generation and concern various types of violence against older people. As its forms, the following are mentioned: lack of care through negligence of duties, physical violence (including injury or loss of health or life), financial violence (sometimes total deprivation of property), sexual and psychological violence (through intimidation or coercion to specific behaviours or decisions) [17-18].

\section{MATERIALS AND METHOD}

The validation procedure was carried out on a sample of 304 adults from the Lublin Province in eastern Poland. Detailed characteristics of the studied population are presented in Table 1.

The mean age of the respondents was almost 30 years $(M=$ $29.85 ; S D=12.26)$. The youngest person was 18 -years-old, and the oldest was 65 . The examined group was homogeneous when gender (50.0\%) and marital status (25.0\%) are considered. The population was dominated by people who had received secondary education $(40.1 \%)$ and came from a city with over 100,000 inhabitants (37.8\%).

The research was carried out using the J. Łukasiewicz and W. Kowalski Scale for Evaluating Attitudes towards Seniors, IVE Impulsiveness Questionnaire in the Polish adaptation by A. Jaworowska [19], and SES Self-Assessment Scale in the Polish adaptation by I. Dzwonkowska I, K. LachowiczTabaczek and M. Laguna [20].

Construction work on Scale for Evaluating Attitudes towards Seniors were carried out from 2017. The initial version of the tool included 100 items containing statements of a positive and negative nature, which concerned the

Table 1. Characteristic of the validation sample

\begin{tabular}{llcc}
\hline Variables & & $\mathrm{M}$ & $\mathrm{SD}$ \\
\hline Age & & 29.85 & 12.26 \\
\hline No. of children & & 1.66 & 0.48 \\
\hline \multirow{3}{*}{ Gender } & women & $N$ & $\%$ \\
\cline { 2 - 4 } & men & 152 & 50.0 \\
\hline \multirow{3}{*}{ Place of residence } & countryside & 152 & 50.0 \\
\cline { 2 - 4 } & town up to 100 thousand residents & 87 & 28.6 \\
\cline { 2 - 4 } & city over 100 thousand residents & 115 & 37.8 \\
\hline \multirow{3}{*}{ Marital status } & spinster/bachelor & 76 & 25.0 \\
\cline { 2 - 4 } & married & 76 & 25.0 \\
\cline { 2 - 4 } & divorced & 76 & 25.0 \\
\cline { 2 - 4 } & widow/widower & 76 & 25.0 \\
\hline & elementary/basic vocational & 66 & 21.7 \\
\cline { 2 - 4 } Level of education & secondary & 116 & 40.1 \\
\cline { 2 - 4 } & higher & 38.2 \\
\hline
\end{tabular}

$M$ - mean; $S D$ - standard deviation; $N$ - total number.

Source: own research results. functioning of older people. They referred to the spheres of family and social life, personality and economic aspects, intergenerational relations, health and medical care, including commonly known stereotypes. With the help of competent judges, 72 items were selected, which, in their opinion, best characterized the elderly in the previously mentioned areas of functioning.

The IVE questionnaire is designed to evaluate three components of personality, pursuant to Eysenecks' concept: impulsiveness, venturesomeness and empathy [19]. According to the authors, the propensity to risk and impulsiveness refer to people who like new challenges and new experiences characterized by the "thrill of emotions". They are eager to seek such experiences. However, impulsive people do not foresee the consequences of their behaviour, they engage in activities without taking into account the effects of their own decisions. This is what distinguishes them from people who are prone to risk. Empathy characterizes people capable of perceiving the emotions of other people, understanding them, and responding adequately.

The alpha Cronbach's tool coefficients range from 0.590.81 . The questionnaire is recommended for individual and group studies, and the results obtained by the examined person are transformed into a stenographic scale; the higher the score, the higher the severity of the feature [19].

SES scale is used to study self-esteem, defined as a onedimensional construct, which is an explicit, global and positive or negative attitude towards oneself [20]. The questionnaire is characterized by high psychometric properties. The absolute stability coefficient in the group of adults is 0.82 [2]. In order to assess the reliability of the tool for the analyzed population, the alpha Cronbach's coefficient was calculated, and the result was 0.80 .

The tool can be applied to individual diagnosis and in scientific research. The result obtained by the respondent is subject to transformation to sten scores, which make it possible to determine its level in relation to the general population. Results within 1-3 states are treated as low; results in the range from 4-6 indicate moderate self-esteem, and scores ranging from 7-10 sten are considered high [20].

The research performed in 2017 and 2018 was individual and anonymous, among adults who volunteered to participate in the research. Anyone could stop their participation at any time without the need to give explanations. The respondents were provided with all the necessary information and explanations about the conducted research. They were also informed about their purpose and the confidentiality of the collected data. Before starting the response, the respondents were informed about the rules for filling-in the tool in question. In case of doubts they had the opportunity to obtain additional information and explanations from the psychologist conducting the examination. The average test duration was 30 minutes. The data collected during the diagnosis was fed to the IBM SPSS 24 suite, which was used to perform statistical calculations.

The characteristics of the validation test were based on analysis of the distribution of the percentage frequency of the occurrence of qualitative variables, as well as on the values of descriptive statistics - mean, standard deviation, minimum and maximum of quantitative variables. The content validity of the constructed research tool was estimated based on the CVR coefficient, which was calculated using the following formula: 


$$
C V R=\frac{n_{\mathrm{e}}-\frac{N}{2}}{\frac{N}{2}}
$$

where:

$n_{\mathrm{e}}$ - number of judges - experts who have indicated that a given test item plays an essential role for the questionnaire; $N$ - number of judges participating in the assessment of test items [12].

Theoretical accuracy of SEAS was verified by means of exploratory factor analysis with simple Oblimin rotation and Kaiser normalization, and criterion validity was determined on the basis of correlation matrix analyzes between SEAS and IVE \& SES in which, due to the linear nature of the relationship between the parameters considered, the $r$ Pearson correlation coefficient was applied. Reliability of scales was estimated based on the values of alpha Cronbach coefficients and the discriminatory power of the items constituting the considered dimensions. The average level of severity of the three aspects of attitudes towards seniors is based on the mean value and standard deviation. The shape of the distribution of the analyzed factors was estimated using the Kolmogorov-Smirnov test. The values of skewness and kurtosis (tailedness) along with the size of their standard errors were also given. In the conducted analyzes, 0.05 was the assumed threshold level of error of the first type.

\section{RESULTS}

Assessment of the relevance of the tool content was carried out by twelve competent judges - psychologists who, based on a defined universe, determined the degree to which each of the scale items is representative for him/her. Based on these judgments, the content validity ratio $(C V R)$ was calculated for each of the tool items [21]. The range of assessments was $0.83-1.00$, which allows the test items making up the questionnaire to be considered relevant in terms of content.

In order to verify the theoretical validity, exploratory factor analysis was performed using the main component method with simple Oblimin rotation and Kaiser's standardization, for the 72 statements. In the last step of the performed analyzes, the value for the Kaiser-Mayer-Olkin criterion of 0.80 was obtained, which confirms the adequacy of data selection. Bartlett's test of sphericity result indicated that the considered factor model is appropriate $C h i^{2}=6685.12$; $d f=2211 ; p=0.001$. The obtained data confirmed the 3 -factor version of the scale.

Based on the Kaiser criterion, three factors were distinguished as having initial values above 1, which explain a total of $35.9 \%$ of the variance. The values of factor loadings of the determined scales are presented in Table 2, which omits items for which factor load values were less than 0.4 .

Of the 72 test items, 67 were retained, because items that served as factor loads of more than one scale were eliminated. 29 items form the first factor, explaining $17.2 \%$ of the variance. The second factor brings together 22 items and explains $10.4 \%$ of the variance. The third factors included 16 items and explains $8.3 \%$ of the variance.

The first of the identified dimensions included items forming the Respect and Support Scale. A high score on this scale is characteristic for people who refer to elders
Table 2. Factor loads of SEAS

\begin{tabular}{|c|c|c|c|c|c|}
\hline \multicolumn{2}{|c|}{$\begin{array}{c}\text { Factor } 1 \\
\text { Respect and Support }\end{array}$} & \multicolumn{2}{|c|}{$\begin{array}{c}\text { Factor } 2 \\
\text { Rejection and } \\
\text { Misunderstanding }\end{array}$} & \multicolumn{2}{|c|}{$\begin{array}{c}\text { Factor } 3 \\
\text { Social distance }\end{array}$} \\
\hline Item No. & Value & Item No. & Value & Item No. & Value \\
\hline 48 & 0.71 & 56 & 0.66 & 63 & 0.69 \\
\hline 35 & 0.70 & 61 & 0.65 & 51 & 0.66 \\
\hline 58 & 0.69 & 20 & 0.64 & 4 & 0.65 \\
\hline 27 & 0.68 & 19 & 0.63 & 30 & 0.64 \\
\hline 59 & 0.67 & 14 & 0.62 & 42 & 0.63 \\
\hline 60 & 0.66 & 18 & 0.59 & 29 & 0.62 \\
\hline 31 & 0.66 & 57 & 0.59 & 65 & 0.58 \\
\hline 32 & 0.63 & 13 & 0.55 & 25 & 0.58 \\
\hline 44 & 0.62 & 17 & 0.54 & 67 & 0.52 \\
\hline 28 & 0.60 & 15 & 0.53 & 62 & 0.51 \\
\hline 26 & 0.60 & 55 & 0.51 & 64 & 0.49 \\
\hline 49 & 0.60 & 22 & 0.51 & 8 & 0.48 \\
\hline 5 & 0.59 & 38 & 0.51 & 50 & 0.47 \\
\hline 46 & 0.58 & 40 & 0.49 & 34 & 0.46 \\
\hline 43 & 0.57 & 39 & 0.49 & 41 & 0.45 \\
\hline 37 & 0.56 & 12 & 0.49 & 2 & 0.45 \\
\hline 7 & 0.54 & 54 & 0.47 & & \\
\hline 3 & 0.54 & 47 & 0.46 & & \\
\hline 45 & 0.53 & 11 & 0.46 & & \\
\hline 52 & 0.53 & 33 & 0.45 & & \\
\hline 1 & 0.50 & 10 & 0.43 & & \\
\hline 53 & 0.49 & 36 & 0.43 & & \\
\hline 24 & 0.48 & & & & \\
\hline 16 & 0.48 & & & & \\
\hline 23 & 0.47 & & & & \\
\hline 21 & 0.46 & & & & \\
\hline 66 & 0.46 & & & & \\
\hline 9 & 0.45 & & & & \\
\hline 6 & 0.44 & & & & \\
\hline
\end{tabular}

Source: own research results

with great respect and attention. Older people evoke positive emotions and the desire to surround them with proper care. The source of this attitude is the conviction that the elderly are characterized by a great wisdom of life and experience, which they willingly share with others. For them, seniors, through their lives, personality and knowledge, are of great value to the family, the whole of society, and especially the younger generation.

Second factor - Rejection and Misunderstanding characterizes an attitude negatively assessing older people (high score). The sources of this attitude are the pejorative personality traits and the unfavorable behaviour towards others, especially the younger generation. Such features include, above all, irritability, visible dissatisfaction with life, life boredom and lack of ideas for their own, further life. The consequence of such behaviour is the loneliness of the elderly and isolation from loved ones and society, which further intensifies the problems and dissatisfaction of older people. 
Table 3. Relations between SEAS factors and IVE and SES dimensions

\begin{tabular}{llll}
\hline Scale & $\begin{array}{l}\text { Respect and } \\
\text { Support }\end{array}$ & $\begin{array}{l}\text { Rejection and } \\
\text { Misunderstanding }\end{array}$ & Social distance \\
\hline Impulsiveness & $r=-0.22 ; p=0.002$ & $r=0.10 ; p=0.206$ & $r=0.12 ; p=0.096$ \\
\hline Venturesomeness & $r=-0.10 ; p=0.141$ & $r=-0.13 ; p=0.073$ & $r=0.02 ; p=0.737$ \\
\hline Empathy & $r=-0.39 ; p=0.001$ & $r=0.10 ; p=0.208$ & $r=-0.19 ; p=0.006$ \\
\hline Self-evaluation & $r=0.21 ; p=0.003$ & $r=0.01 ; p=0.951$ & $r=-0.16 ; p=0.024$
\end{tabular}

$r$-value of Pearson's linear correlation coefficient $r ; p$ - significance level. Source: own research results.

Third scale - Social distance describes the attitude and distance towards the elderly, emphasizing the awareness of their good economic and social condition (high score). However, excessive attention paid by the elderly to improving the comfort of their life (especially gathering material possessions) without taking into account the needs of others is a source of negative references and emotional (life) distance to older people.

Criterial accuracy of SEAS was estimated based with the analysis of the correlation matrix with the dimensions theoretically associated with attitudes towards seniors, and therefore with three personality factors diagnosed with the IVE Questionnaire - impulsiveness, venturesomeness and empathy, and self-esteem tested using SES scale (Tab. 3).

Correlation analyzes carried out indicate that respect for seniors, on average, positively co-exists with empathy, $r=0.38 ; p=0.001$, weakly in direct proportion to self-esteem, $r=0.25 ; p=0.001$ and weakly negatively with impulsiveness, $r=-0.20 ; p=0.004$. Perception of the economic sphere of seniors is slightly inversely proportional to empathy, $r=-0.17$; $p=0.017$, and also to self-esteem, $r=-0.15 ; p=0.029$.

The obtained data confirm the criterion accuracy of the Scale for Evaluating Attitudes towards Seniors. Reliability of $S E A S$ was estimated on the basis of internal compliance and values of discriminatory power of items that make up the dimensions distinguished. The internal conformity of the tool was verified based on the values of alpha Cronbach coefficients. (Tab. 4). Obtained alpha Cronbach values indicate high reliability of the SEAS.

Table 4. Internal coherence coefficients of SEAS

\begin{tabular}{cc}
\hline Scale & Alpha Cronbach coefficient \\
\hline Respect and Suport & 0.93 \\
\hline Rejection and Misunderstanding & 0.88 \\
\hline Social distance & 0.86 \\
\hline
\end{tabular}

Source: own research results.

Discriminatory powers of items that make up the three individual scales of SEAS are presented in Table 5.

The analyzes carried out revealed high discriminatory powers of all items creating the individual factors. This forms the basis for confirmation of reliability of the 3-factor Scale for Evaluating Attitudes towards Seniors.

Table 6 contains the mean values, standard deviations and measures of the shape of the distribution of three factors in the SEAS questionnaire.

The respondents tend to agree with the statement that they respect seniors $(M=4.43 ; S D=0.60)$. They notice that older people tend to complain about loneliness $(M=3.82$; $S D=0.60)$, and also note that seniors experience difficulties in the sphere related to economics $(M=2.74 ; S D=0.64)$.
Table 5. SEAS discriminatory power values

\begin{tabular}{|c|c|c|c|c|c|c|c|c|}
\hline \multicolumn{3}{|c|}{$\begin{array}{c}\text { Factor } 1 \\
\text { Respect and Support }\end{array}$} & \multicolumn{3}{|c|}{$\begin{array}{c}\text { Factor } 2 \\
\text { Rejection and } \\
\text { Misunderstanding }\end{array}$} & \multicolumn{3}{|c|}{$\begin{array}{c}\text { Factor } 3 \\
\text { Social distance }\end{array}$} \\
\hline $\begin{array}{l}\dot{\circ} \\
\stackrel{一}{\Phi} \\
\stackrel{ \pm}{ \pm}\end{array}$ & 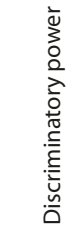 & 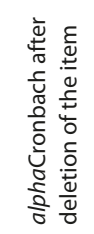 & $\begin{array}{l}\stackrel{\dot{0}}{\subseteq} \\
\stackrel{\Xi}{ \pm}\end{array}$ & 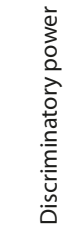 & 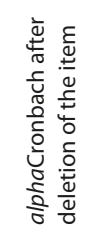 & $\begin{array}{l}\stackrel{\dot{\Xi}}{E} \\
\stackrel{\varepsilon}{\Phi} \\
\stackrel{ \pm}{ \pm}\end{array}$ & 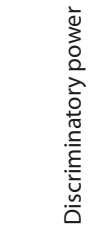 & 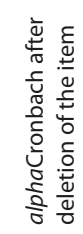 \\
\hline 48 & 0.65 & 0.92 & 56 & 0.61 & 0.87 & 63 & 0.65 & 0.84 \\
\hline 35 & 0.67 & 0.92 & 61 & 0.60 & 0.87 & 51 & 0.59 & 0.84 \\
\hline 58 & 0.68 & 0.92 & 20 & 0.58 & 0.87 & 4 & 0.59 & 0.84 \\
\hline 27 & 0.63 & 0.92 & 19 & 0.57 & 0.87 & 30 & 0.51 & 0.85 \\
\hline 59 & 0.63 & 0.92 & 14 & 0.58 & 0.87 & 42 & 0.58 & 0.84 \\
\hline 60 & 0.62 & 0.92 & 18 & 0.53 & 0.88 & 29 & 0.56 & 0.85 \\
\hline 31 & 0.65 & 0.92 & 57 & 0.53 & 0.88 & 65 & 0.51 & 0.85 \\
\hline 32 & 0.60 & 0.92 & 13 & 0.51 & 0.88 & 25 & 0.44 & 0.85 \\
\hline 44 & 0.57 & 0.92 & 17 & 0.47 & 0.88 & 67 & 0.37 & 0.85 \\
\hline 28 & 0.56 & 0.92 & 15 & 0.48 & 0.88 & 62 & 0.40 & 0.85 \\
\hline 26 & 0.55 & 0.92 & 55 & 0.46 & 0.88 & 64 & 0.47 & 0.85 \\
\hline 49 & 0.56 & 0.92 & 22 & 0.44 & 0.88 & 8 & 0.42 & 0.85 \\
\hline 5 & 0.58 & 0.92 & 38 & 0.44 & 0.88 & 50 & 0.44 & 0.85 \\
\hline 46 & 0.54 & 0.92 & 40 & 0.44 & 0.88 & 34 & 0.41 & 0.85 \\
\hline 43 & 0.54 & 0.92 & 39 & 0.41 & 0.88 & 41 & 0.39 & 0.85 \\
\hline 37 & 0.53 & 0.92 & 12 & 0.42 & 0.88 & 2 & 0.41 & 0.85 \\
\hline 7 & 0.49 & 0.92 & 54 & 0.43 & 0.88 & & & \\
\hline 3 & 0.50 & 0.92 & 47 & 0.37 & 0.88 & & & \\
\hline 45 & 0.47 & 0.92 & 11 & 0.42 & 0.88 & & & \\
\hline 52 & 0.50 & 0.92 & 33 & 0.37 & 0.88 & & & \\
\hline 1 & 0.48 & 0.92 & 10 & 0.39 & 0.88 & & & \\
\hline 53 & 0.43 & 0.92 & 36 & 0.34 & 0.88 & & & \\
\hline 24 & 0.45 & 0.92 & & & & & & \\
\hline 16 & 0.45 & 0.92 & & & & & & \\
\hline 23 & 0.40 & 0.93 & & & & & & \\
\hline 21 & 0.41 & 0.93 & & & & & & \\
\hline 66 & 0.41 & 0.93 & & & & & & \\
\hline 9 & 0.44 & 0.92 & & & & & & \\
\hline 6 & 0.43 & 0.92 & & & & & & \\
\hline
\end{tabular}

Source: own research results

To summarize the validation work, it should be pointed out that the Scale for Evaluating Attitudes towards Seniors (SEAS) contains 67 statements to which the respondents reply, based on a 6-point Likert-scale, which accepts the range from completely disagreeable - (1) to completely agree - (6). The 
Table 6. Values of descriptive statistics and measures of the distribution of SEAS factors

\begin{tabular}{lccccccc}
\hline Scale & $\boldsymbol{M}$ & $\boldsymbol{S D}$ & $\boldsymbol{S}$ & $\boldsymbol{S E}_{\boldsymbol{S}}$ & $\boldsymbol{K}$ & $\boldsymbol{S E}_{\boldsymbol{K}}$ & $\boldsymbol{K}-\boldsymbol{S}$ \\
\hline Respect and Support & 4.43 & 0.60 & -0.06 & 0.17 & -0.22 & 0.34 & $\begin{array}{l}Z=0.51 ; \\
p=0.960\end{array}$ \\
\hline $\begin{array}{l}\text { Rejection and } \\
\text { Misunderstanding }\end{array}$ & 3.82 & 0.60 & -0.31 & 0.17 & 2.09 & 0.34 & $\begin{array}{l}Z=0.99 ; \\
p=0.283\end{array}$ \\
\hline Social distance & 2.74 & 0.64 & 0.58 & 0.17 & 0.62 & 0.32 & $\begin{array}{l}Z=1.09 ; \\
p=0.189\end{array}$ \\
\hline
\end{tabular}

$M$ - mean; $S D$ - standard deviation; $S$ - skewness; $S E_{s}$ - standard error of skewness; $K$ - kurtosis; $S E_{K}-$ standard error of kurtosis; $K-S$-Kolmogorov-Smirnov test verifying the distribution shape; $Z$-value of Kolmogorov-Smirnov test statistic; $p$ - significance level.

Source: own research results.

respondent's task is to circle the selected number reflecting their belief in a given issue.

SEAS is a self-report tool, and takes about 15 minutes to complete. The test can be conducted individually or in groups. The questionnaire contains instructions.

Scale is used in the diagnosis of adults, both healthy and sick, and its high psychometric properties allow use of the tool in individual diagnosis and in scientific research.

The Scale for Evaluating Attitudes towards Seniors consists of three factors: 1) Respect and Support, 2) Rejection and Misunderstanding, 3) Social distance. Each dimension is considered separately.

The result obtained by each respondent is calculated by adding points for particular items that make up a given scale. Next, the weighted average of each scale is calculated by dividing the result obtained by the number of items of the respective factor. The higher the score, the higher the severity of the dimension that makes up attitudes towards seniors.

\section{DISCUSSION}

The research conducted in Poland on attitudes towards older people does not allow for their unambiguous assessment and characterization. The bipolarity in the perception of the oldest generation is evident. A positive image of an experience-rich older man clashes with a negatively perceived, awkward, irritable man who at the end of his life is a burden on family and society. In some way - though not completely - this is confirmed by the presented SEAS tool.

The mean score (4.43) obtained in the first scale of Respect and Support indicates a positive (to a moderate degree) perception of older people, as experienced in life, sharing their knowledge and wisdom with others, arousing positive emotions, respect and recognition in the environment. This attitude is accompanied by readiness to help the elderly, willingness to support and care, among others, as an expression of gratitude for what they have done in their lives for the new generation. Similar results can be found in other studies [1,15-16, 22-23], but may not always be so expressive. This approach is characterized by balanced, reasonable people with a relatively high level of self-esteem, empathic.

Referring to the results of the Rejection and Misunderstanding scale there is a tendency to negatively perceive elderly people who isolate themselves or are isolated by society. The reason for this is the sensitive behaviour of these people, life negativity, frustration, aversion and lack of understanding for the younger generation. Other researchers also obtained this type of results [15-6, 22-24]. In many cases, especially when it comes to the younger generation $[1,15-16]$, the results were even more intense.

Results obtained by the respondents on the third - Social distance-scale show that they tend not to share opinions about seniors as people exaggerating their material goods, whose socio-economic situation is quite satisfactory. As a result, here, the desire to be in relatively close relationships with the older generation can be indicated, with the awareness of their needs for support [22-23, 25].

The comprehensive analysis of the research results therefore indicates quite polarized attitudes towards seniors. However, the tendency to perceive them in a positive light prevails. There is also a common context of these attitudes, namely, personality traits expressed in the behaviour of older people, relationships with others, especially with the younger generation, the level of life satisfaction as a result of summarizing the past, economic and health condition. These are factors that seem to play an important role in shaping the image of an elderly person. Certainly one should take into account the variables mentioned by other researchers, these include age, gender of the respondents, level of education or personal experience with older people, or the environment in which the seniors live $[6,15-16,26-29]$.

The presented tool can also be a good complement to the scales used to assess attitudes related to ageism. Although there are many studies showing the social perception of older people, the majority of the well-tested tools are not available in Polish [13]. The SEAS scale is somewhat close to the Fraboni of Ageism Scale (FSA) [30], Aging Semantic Differential Scale (ASD) [31], or the Kogan Attitudes Towards Older People Scale $(K O P)[14,32]$. However, it does not study knowledge about older people or the aging process itself. Still it focuses on the image of older people in social perception, emotional attitude, and the possible sources of attitudes presented. It should also be emphasized that due to high psychometric properties, the questionnaire can be used both in individual diagnosis and scientific research which, in turn, will contribute to broadening knowledge about the psychological mechanisms associated with seniors' perception, and can be used to design responses to preventive actions supporting quality of intergenerational interpersonal interactions.

\section{CONCLUSIONS}

1. Validation procedure carried out for the Scale for Evaluating Attitudes towards Seniors (SEAS) confirms the high psychometric properties of the constructed research tool:

- the content relevance ratio CVR ranges from 0.83-1.00;

- the factor analysis performed positively verified the theoretical validity of a scale consisting of 3 factors (Respect, Loneliness, Economy);

- conducted correlation matrix analyzes confirm SEAS criterion validity;

- the values of the alpha Cronbach's coefficient for the respective scales are as follows: Respect 0.93 ; Loneliness - 0.88, Economy - 0.86 .

- the items that make up the separated factors have high values of discriminatory powers;

2. The SEAS questionnaire can be used both in individual diagnosis and in scientific research. 


\section{REFERENCES}

1. Miałkowska G. Analiza postaw społecznych wobec ludzi starszych na podstawie opinii studentów. Prace Naukowe Akademii im. Jana Długosza w Częstochowie. 2014; XVI: 177-192.

2. Nicole-Urbanowicz J. Ageizm i dyskryminacja ze względu na wiek. Witryna Wiejska, 2015.

3. Rup DE, Vodanovich SJ, Crede M. The multidimensional nature of ageism: Construct validity and group differences. Journal of Social Psychology. 2005; 145: 335-362.

4. Holroyd A, Dahlke S, Ferh C, Jung P, Hutner A. Attitudes toward aging: implications for a caring profession. J Nurs Educ. 2009; 48(7): 374-380

5. Palmore E. Three decades of research on ageism. Generations. Journal of the American Society on Ageing, 2005; 29: 87-90.

6. Cichocka M. Zjawisko i formy przemocy wobec ludzi starych. In: Bińczycka-Anholcer M, editor. Agresja i przemoc a zdrowie psychiczne. Polskie Towarzystwo Higieny Psychicznej, Warszawa-Poznań; 2001. pp. 214-215.

7. Kalfoss $\mathrm{MH}$. Attitudes to ageing among older Norwegian adults living in the community. Br J Community Nurs. 2017; 2, 22(5): 238-245.

8. Rush KL, Watts WE, Stanbury J. Older adults' perceptions of weakness and ageing. Int J Older People Nurs. 2013; 8(1): 1-9.

9. Wisdom NM. Social acceptance of age discrimination. Oklahoma Christian University Edmond, 2010.

10. Henderson J, Xiao L, Siegloff L, Kelton M, Paterson J. Older people have lived their lives': First year nursing students' attitudes towards older people. Contemp Nurse. 2008; 30(1): 32-45.

11. Lee YS. Measures of student attitudes on ageing. Educ Gerontol. 2009; 35(2): 121-134.

12. Cozort R.W. Student nurses' attitudes regarding older adults: Strategies for fostering improvement through academia. Teaching and Learning in Nursing. 2008; 3(1): 21-25.

13. Strugała M, Zielińska A, Dymek-Skoczyńska A, Czyżewska-Torba P. Narzędzia pomiarowe służące ocenie postaw społecznych względem osób starszych - krótka charakterystyka. Nowiny Lekarskie. 2013; 82(1): 70-75

14. Kogan N. Attitudes toward old people: The development of a scale and an examination of correlates. Journal of Abnormal and Social Psychology. 1961; 62: 44-54.

15. Pakos E. Ludzie starzy w oczach młodzieży - wyniki badań własnych. Folia Oeconomica. Acta Universitas Lodzensis. 2017; 3(329): 167-177.

16. Krupa B. Starość w percepcji młodzieży - perspektywa pedagogiczna. Nowiny Lek. 2012; 81: 36-43.
17. Sygit E, Ossowski R. Przemoc wobec osób starszych ze względu na ich wiek, płeć i wykształcenie. Gerontol Pol. 2008; 16(3): 163-168.

18. Cichocka M. Zjawisko i formy przemocy wobec ludzi starych. In: Bińczycka-Anholcer M, editor. Agresja i przemoc a zdrowie psychiczne. Polskie Towarzystwo Higieny Psychicznej, Warszawa-Poznań; 2001. pp. 214-215.

19. Jaworowska A. Kwestionariusz impulsywności IVE HJ. Eysenck’a i SBG. Eysenck'a. Polska normalizacja. Warszawa PTP, 2011.

20. Dzwonkowska I, Lachowicz-Tabaczek K, Łaguna M. Samoocena i jej pomiar. Polska adaptacja Skali SES M. Rosenberga. Warszawa PTP, 2008 .

21. Hornowska E. Testy Psychologiczne. Teoria i Praktyka. Warszawa Scholar, 2013

22. Dąbska O, Pawlikowska-Łagód K, Piasecki J, Śledziewska K, Humeniuk E. Starość i samotność osób starszych w percepcji ludzi młodych. Med Ogól Nauki Zdr. 2016; 22(2): 140-144.

23. Wądłowska K. Polacy wobec ludzi starszych i własnej starości. Warszawa: Centrum Badania Opinii Społecznej, 2009.

24. Warmoth K, Tarrant M, Abraham C, Lang IA. Older adults' perceptions of ageing and their health and functioning: a systematic review of observational studies. Psychol Health Med. 2016; 21(5): 531-550.

25. Ziomek-Michalak K. Starzenie się i starość w percepcji studentów przygotowujących się do zawodu pracownika socjalnego. Gerontol Pol. 2016; 24: 167-175.

26. Matarese M, Lommi M, Pedone C, Alvaro R, De Marinis MG. Nursing student attitudes towards older people: validity and reliability of the Italian version of the Kogan Attitudes towards Older People scale. J Ad Nurs. 2012; 69(1): 175-184.

27. Dąbska O, Pawlikowska-Łagód K, Humeniuk E. Old age as a (non-) media phenomenon. Gerontol Pol. 2017; 25(2): 118-122.

28. Pawlikowska-Łagód K, Dąbska O, Humeniuk E, Sak J. Geriatria. 2017; 11(3): 183-189.

29. Humeniuk E. Zaburzenia mowy w podeszłym wieku. In: Patologia mowy. Tarkowski Z, editor. Harmonia Universalis, Gdańsks; 2017. pp. 103-119.

30. Iwasaki M, Jones JA. Attitudes Toward Older Adults: A Reexamination of Two Major Scales. Gerontol Geriatr Educ. 2008; 29(2): 139-157.

31. Fraboni M, Saltstone R, Hughes S. The Traboni Scale of Ageism (FSA) An Attempt at More Precise Measure of Ageism. Can J Aging. Bodner E, Cohen-Fridel S. Relations between attachment styles, ageism and quality of life in late life. Int Psychogeriatr. 2010; 22(8): 1353-1361.

32. Rodgers V, Gilmour J. Shaping student nurses' attitudes towards older people through learning and experience. Nurs Prax N Z. 2011; 27(3): $13-20$. 